\title{
Teachers' Personal Characteristics and Metaphorical Perceptions to Multicultural Education
}

\author{
Menekşe Eskici ${ }^{1}$, Semih Çayak ${ }^{2}$ \\ ${ }^{1}$ Assist Prof. Dr. Kurklareli University, Faculty of Art and Science, Educational Sciences Department, Turkey \\ ${ }^{2}$ Teacher, Republic of Turkey Ministry of National Education, Turkey \\ Correspondence: Menekşe Eskici, Assist Prof. Dr. Kırklareli University, Faculty of Art and Science, Educational \\ Sciences Department, Turkey.
}

Received: January 14, 2018

doi:10.11114/jets.v6i3a.3163
Online Published: April 1, 2018

URL: https://doi.org/10.11114/jets.v6i3a.3163

\begin{abstract}
The aim of this paper is to investigate teachers' personal characteristics and metaphorical perceptions to multicultural education. In this paper both quantitative and qualitative data were collected. "Multicultural Personality Questionnaire" was applied to the teachers ( 72 females, 47 males) working at Kurklareli in the 2016-2017 academic year to collect the quantitative data. The qualitative data of this research were collected by a space filled question (multiculturalism is similar to...; because...). The results show that teachers have high scors of "Multicultural Personality Questionaire". The metaphorical images that teachers produce for the concept of multiculturalism are examined in terms of frequency. The results listed as rainbow, ashure, mosaic, rug, greenery, spice, garden, crayons, treasure, cake, music, forest, salad, table and meal. Also reasons for analogy of the metaphors that teachers use about the concept of multiculturalism arrenged as; the union of differences $(n=81)$, which benefit $(n=22)$, value-added $(n=8)$, the parser $(n=3)$ and unknown $(n=2)$.
\end{abstract}

Keywords: multicultural personality, metaphorical perceptions, multiculturalism

\section{Introduction}

In the globalizing world, depending on the interaction of individuals or a major rapid progress of society, it has emerged the necessity of living together in different cultures (Türkan, Aydın \& Üner, 2016). Particularly, migration phenomena that have taken place with the transition from agricultural society to industry and information society, the existence of unities created by economic and social etc. aims among countries, the transition from locality to universality, have led to the recognition of different cultures and accelerated cultural interaction (Cirık, 2008). This has brought about multiculturalism policies that people have been trying to recognize the diversity within their own cultures and to look at different cultures with tolerance and instead of suppressing them (Giddens, 2000; Demir \& Başarır, 2013).

It has been argued in the literature that there are many definitions with regard to multiculturalism, but the concept is often incorrectly defined (Connors-Stack, 1995). In this context, it would be more accurate to state what the culture means first before making the definition of multiculturalism. There are many different definitions of culture made by different researchers in the literature. For example, Yakışır (2009) defined culture as characteristics that make a person human, are influential at all stages and are inherited from generation to generation by socialization; Parekh (2002) defines culture as a system of meanings and beliefs created within history and a system of beliefs and customs that they use in order to understand, organize, and structure the individual and collective life of a group of people. Duverger (2004) defines it as a set of regulated behaviors and whole of thoughts and perception, which constitute the roles that determine the behaviors expected from a human community. As it is clear from the definitions, each researcher tried to define the culture by focusing on a different point of the concept of culture. Titrek (2010) has emphasized that cultural relations are an important determinant of human relations.

In general, multiculturalism (Özdemir \& Dil, 2013), a term used to describe the cultural diversity in the social fabric, relies on different backgrounds and origins in different countries (Race, 2011). Multiculturalism has been a concept that influences the whole world, although the effect differs according to the countries. Whereas Kaya (2007) defines the concept of multiculturalism as ideally the modern society covers different cultural groups and these different groups have equal status, Yakışır (2009) describes multiculturalism as a cohabitation project.of communities which come from different cultures and from different ethnic and cultural backgrounds which have different religions, languages, races. 
On the other hand, APA (2002) defines multiculturalism as an understanding of the racial, ethnic, language, sexual orientation, gender, age, disability, social class, education, religious orientation and other cultural dimensions. As previous definitions of multiculturalism have shown, a multicultural life can be seen as showing understanding to differences within society and creating a common culture by securing the equality of differences. Indeed, it is meant that multicultural understanding is not only about respect for differences but also for ensuring the legal equality of differences (Özodaşık, 2009). From this point of view, it is considered that acquiring a multicultural understanding of individuals is closely related to a multicultural education.

Knowledge, attitudes and skills such as building cultural awareness, developing a multidimensional perspective, adopting a democratic society structure, providing critical thinking about prejudices, refusing any discrimination with a humanistic approach can only be achieved through multicultural education practices in the individuals who have a a heterogeneous structure in terms of language, religion and belief, ethnicity, race and social norms and in other words who are multicultural society (Demir, 2012). As Cirik (2008) pointed out, multicultural education focuses on the differentiation of learning environments in order to ensure that students are welcome in different cultures. For this, teachers should create learning environments that will allow their students to respect the values of individuals outside their own cultures, remove prejudices against different cultures, and adopt differences which are a richness for people.

Intercultural education is one of the most important areas of education in the twenty-first century and, in the historical context, it is seen that intercultural encounters often handled together with violence, ethnic cleansing and genocide. For this reason, it is thought that education systems should aim to prepare citizens to live in a multicultural and different state (Tabatadze, 2015). In this context different cultural perspectives, the relative importance of cultural qualities and knowledge within the school system and the differences of minorities are at the heart of the multicultural education debate (Connors-Stack, 1995). The most important prejudice or lack of knowledge on multicultural education, which is seen to have increased importance in scientific studies with the increase in multicultural education practices in multinational and multicultural societies, is to see it only as a matter related to ethnic problems (Demir 2012). On the contrary, multicultural education supports values such as respect for diversity, understanding of other cultures, tolerance and equal opportunities for every member of society. Hence, multiculturalism is defined not only in terms of ethnicity or language, but also in a broad sense, including gender, social-economic status, religion, special needs, or ethical orientation (Todor, 2015).

Multicultural education (Mitchell \& Salsbury, 2000) is a conceptual educational reform process aimed at creating equality for all students, recognizing students' differences, cultural backgrounds, taking into account the economic and racial backgrounds of each student, and creating a classroom environment with all students and without discrimination (Banks \& Banks, 2007). Because Nieto (2002) has also referred special qualifications to multicultural education and stated that multicultural education is a dynamic process that aims to be inclusive. Manning and Baruth (2009) argue that multicultural education is designed to teach students to recognize, acknowledge and appreciate differences in culture, ethnicity, social class, sexual orientation, religion, special needs and gender, and to possess democracy, equality and justice.

Banks (1993) described the dimensions of multicultural education as (a) content integration, (b) information creation process, (c) bias reduction, (d) equality education and (e) strengthening school culture, and then he explained these dimensions as follows: Content integration is a dimension to teachers who represent their curricula in various cultures. The process of knowledge creation is a dimension that represents teachers who help students create meaning from what is offered to them. The reduction of prejudice implies that teachers use lessons to help develop positive attitudes towards various racial, ethnic and cultural groups. Having an egalitarian pedagogy suggests that teachers teach all learners in a way that they can achieve academic success. Finally, a strengthening school culture is a culture that promotes gender, race and social class equality (Hamilton, 2015). Multicultural approaches include a set of strategies designed to help all students develop "the knowledge, skills and attitudes they need to become active citizens in a democratic society and participate in social change" (Valdez, 1999). Thus, multicultural education has the characteristics to transform the problems arising from ethnic and cultural differences into the public benefit for the benefit of society through appropriate discussion, communication and negotiation and so to provide democratic development (Banks, 1992).

Nieto and Bode (2008) offer three goals for effective multicultural education, these are;

A. Handle harder questions on stratification and inequality

B. Place learning in the center

C. Encourage democracy by preparing students to contribute not only to their own interests but to the general well-being of the community. 
In a world of rapidly changing demographic structure, multicultural education that has become a priority is seen as a means to increase cultural awareness and respect diversity, to "consolidate social identity, reduce stereotyping, prejudice and discrimination" of people. The main objectives of multicultural education (Todor, 2015), which is a student-centered approach that focuses on using familiar contexts as learning opportunities, integrating cultural backgrounds into the learning process, critical thinking and developing diversity of views, are listed as follows by Gay (1994):

- Individual development: To ensure that the individual understands himself, develops a positive self, and is at peace with his identity.

- Multicultural social competence: To encourage individuals to see intercultural communication, structures of different cultures, and alternative perspectives.

- Basic skill acquisition: To help students with different ethnic backgrounds acquire basic skills (reading and writing, mathematics, problem solving, critical thinking, etc.).

- Developing cultural and ethnic literacy: To enable individuals to recognize and respect the cultural and ethnic differences that exist in society, as well as their own cultures.

- Explain values and attitudes: To explain the values and attitudes of individuals belonging to different cultures to ensure that other individuals recognize and respect these cultures.

Bennett (2007) collected 8 main topics which support the main objectives of the multicultural education stated by Gay (2004). These are listed as follows: 1. Providing critical thinking about prejudice, 2. Increasing respect and tolerance, 3. Increasing academic achievement, 4. Teaching to live in harmony 5. Creating cultural awareness, 6. Providing pluralism and equality, 7. Increasing communication among different groups, 8. Developing self-confident identities, 9. Cooperating in sharing basic skills and abilities.

Multicultural education is the educational strategy that is used to develop effective educational processes and school settings that the culture of the students, "supports and spreads the concepts of culture, diversity, equality, social justice and democracy in the school environment" (Gollnick \& Chinn, 2009). Thus, in recent years, multicultural education has been widely portrayed as an educational approach to social and cultural diversity in individual countries. Increasing the multicultural awareness of students has been considered as a vital tool to promote social cohesion, especially in high-diversity countries. As the pace of economic and cultural globalization increases, the importance of multicultural competence put forward by students has more attracted the attention of educations scheme managers and researchers (Cha \& Ham, 2014).

Multicultural education (Banks \& Banks, 2007), considered as a conceptual educational reform process aiming to create equality for all students, is one of the most studied and debated topics in education today. Multicultural education is concerned with students to know their differences and recognizes their own cultural backgrounds, taking into account the economic and racial backgrounds of each student, and creating a classroom environment with all the students involved and without discrimination (Mitchell \& Salsbury, 2000). As a matter of fact, teachers are necessary to understand the philosophy of multicultural education very well in order to educate individuals who know their own cultures and live their own cultures but respect others. With the understanding of the importance of multicultural education, it is thought that the teachers, who are the guides of the teaching process, will influence their thinking, perceptions, and competencies in the process of education and the education of the student. For this reason, it has been deemed necessary to determine the metaphorical perceptions of teachers' multicultural personality and multiculturalism.

\section{Problem Statement and Sub-Problems (Hypotheses)}

The aim of this paper is to investigate teachers' personal characteristics and metaphorical perceptions to multicultural education.

1. How are teachers' personal characteristics and metaphorical perceptions to multicultural education?

2. How are teachers' metaphorical perceptions to multicultural education?

3. How are reasons for analogy of the metaphors that teachers use about the concept of multiculturalism?

\section{Method}

This section contains information on the design of the study, study group, data collection tools, collection and analysis of data.

\subsection{Method of the Research}

In this study which was examined personality traits of teachers towards multicultural education and the metaphorical perceptions of teachers towards multicultural education, a screening model was used from the quantitative research 
types and a phenomenology design was used from the qualitative research types. In this respect the study is designed with mixed method. There are five main purposes of mixed method research. These are triangulation, completion, development, initiation and expansion. The reason for the preference the mixed method in this study is determined as triangulation. Triangulation is the use of qualitative and quantitative data at the same time, but independently, to study the same phenomenon (Greene Caracelli \& Graham, 1989; Giannakaki, 2005).

It was preferred concurrent triangulation from mixed method research designs in this study. In this design, where quantitative and qualitative data are collected and analyzed at the same time, the priority is equal in both data types. This design is useful when it is aimed at validating, strengthening, and looking at cross validity of research findings (Creswell, 2003; Baki \& Gökçek, 2012 ).

\subsection{Population-Sampling}

The sample of this study was selected as a concurrent mixed method sample. Indeed, the sampling of the concurrent mixed method allows triangulation of the results of the researcher separately from the quantitative and qualitative components of the study, thus allowing verification, support, or cross validation of findings within a single study (Creswell et al., 2003). In this study, scale data and metaphors will also be collected at the same time. In order to express the personality traits of the teachers for the multicultural education, the scale was applied to 207 teachers who were selected by simple unselected sampling method and working in the province of Kırklareli. However, the scale returned from only 119 teachers was taken into account as it was thought to be filled in properly. 72 were female and 47 were male of these teachers.

\subsection{Data Collection Tools}

"Multicultural Personality Questionnaire" was developed by Van Der Zee \& Van Oudenhoven (2002) and adapted to Turkish by Polat (2009) was used to collect the quantitative data. The qualitative data of this research were collected by a space filled question (multiculturalism is similar to...; because ...).

\subsection{Reliability and Validity of Data}

Reliability coefficient of "Multicultural Personality Questionnaire" has been found as .82 by Polat (2009). Also the scale is accepted as a validity data collection tools. To calculate the reliability of the content analysis for qualitative data analysis the data Were separately coded by two researcher. The results were matched Considering the formula "Reliability $=$ Consensus / Consensus + Disagreement x 100". The match rate between the two encoders is calculated as .82. it is accepted as reliability (Miles \& Huberman 1994).

\subsection{Analysis Techniques}

SPSS 17 was used to analyze mean and standard deviation of sub-dimensions and items of "Multicultural Personality Questionnaire". The qualitative data of collected were analyzed through content analysis technique. The answers given by the teachers were analyzed in four stages; 1 . coding the data, 2. creating the categories, 3 . arranging the data according to the codes and categories and 4. ensuring the validity and reliability. Content analysis is carried out when the research is not theoretically expressible or where a more in-depth analysis is needed (Yıldırım \& Şimşek, 2013). The data were analyzed by the researchers themselves without any qualitative analysis program. It is coded by giving a number for each participant. For example; Teacher 5: 5th Teacher where the metaphor is taken

\section{Findings}

This section constitutes the findings related to research. Comments on the subject were included.

\subsection{Findings and Comments From Quantitative Research}

Findings and comments are included in this section. Findings related to the subproblems of the research are also presented by creating tables in this section.

\subsection{Teachers' Level of Having Personality Traits for Multicultural Education}

The mean and standard deviation values of obtained from "Multicultural Personality Questionnaire" applied to determine whether teachers have multicultural educational personality traits are presented in Table 1. 
Table 1. Mean and standard deviation values of the scale

\begin{tabular}{|c|c|c|c|}
\hline Items & $\mathrm{N}$ & $\bar{x}$ & SS. \\
\hline 1. I can easily communicate. & 119 & 4,03 & ,99 \\
\hline 2. I have difficulty communicating with others. & 119 & 2,03 & 1,17 \\
\hline 3. I try to understand what others feel. & 119 & 4,26 &, 84 \\
\hline 4. I try to understand people's behavior & 119 & 4,29 &, 80 \\
\hline 5. I avoid surprises & 119 & 2,29 & 1,15 \\
\hline 6. I stay calm when in misfortune. & 119 & 3,23 & 1,19 \\
\hline 7. I give communication priority to others. & 119 & 2,99 & 1,14 \\
\hline 8. I can easily participate different groups. & 119 & 3,71 & 1,05 \\
\hline 9. My calmness gives peace to my surroundings. & 119 & 3,50 & 1,14 \\
\hline 10. I easily warm towards other people. & 119 & 3,88 & ,97 \\
\hline 11. I mostly work according to a strict schedule. & 119 & 2,53 & 1,25 \\
\hline 12. I like to speak openly in a community I do not know. & 119 & 3,00 & 1,22 \\
\hline 13. I work according to plan. & 119 & 3,49 & 1,11 \\
\hline 14. I feel under pressure & 119 & 2,53 & 1,18 \\
\hline 15. I understand the feelings of others. & 119 & 4,25 &, 72 \\
\hline 16. I pay attention to the face expressions of others and I care about them & 119 & 4,44 & 69 \\
\hline 17. Failed and pessimistic situations affect my perspective. & 119 & 3,51 & 1,23 \\
\hline 18. I try different approaches. & 119 & 4,08 &, 85 \\
\hline 19. Differences attract my interest. & 119 & 4,38 & ,68 \\
\hline 20. I can easily start a new life & 119 & 3,29 & 1,10 \\
\hline 21. I'm interested in life stories of other people and try to understand it & 119 & 4,18 & ,79 \\
\hline 22. I can easily get into other cultures. & 119 & 3,68 & ,92 \\
\hline 23. I am a person who can easily upset. & 119 & 3,48 & 1,25 \\
\hline 24. I'm a worried person. & 119 & 3,22 & 1,30 \\
\hline 25. I notice when somebody's in trouble. & 119 & 4,17 & ,78 \\
\hline 26. I try to understand the nature of man. & 119 & 4,17 & ,77 \\
\hline 27. I feel alone myself. & 119 & 2,61 & 1,28 \\
\hline 28. I try to communicate with people from a different background. & 119 & 3,91 & 1,00 \\
\hline 29. I feel when others are uncomfortable. & 119 & 4,28 &, 81 \\
\hline 30. I understand others and relax them. & 119 & 4,09 & ,93 \\
\hline 31. I work according to strict rules. & 119 & 2,70 & 1,24 \\
\hline 32. I attach importance to the feelings of others. & 119 & 4,26 & ,76 \\
\hline 33. I like to learn from others. & 119 & 4,24 & ,91 \\
\hline
\end{tabular}

As seen in Table 1, teachers have participate "I pay attention to the face expressions of others and I care about them" (item 16) $(\bar{X}=4.44)$, "Differences attract my interest" (item 19) $(\bar{X}=4.38)$, "I try to understand people's behavior" (item 4) $(X=4.29)$ and "I feel when others are uncomfortable" (item 29$)\left(X_{=} 4.28\right)$ at the highest level respectively, in terms of their level of having personality traits for multicultural education.

According to Table 1, Teachers have participated "I have difficulty communicating with others" (item 2$)(\bar{X}=2.03)$, "I avoid surprises" (item 5) $(\bar{X}=2.29)$, " I mostly work according to a strict schedule" (item 11) $(\bar{X}=2.53)$ and "I feel under pressure" (item 14) $\left(X_{=}=2.53\right)$ at the lowest level, respectively, in terms of their having personality traits for multicultural education.

When the mean and standard deviation values were examined, it was observed that the arithmetic mean values of the items changed between 2.03 and 4.44 in order to determine whether the teachers had personality traits for multicultural education. The arithmetic mean and standard deviations of the sub-dimensions of the scale were calculated and the findings are presented in Table 2 to determine the degree to which teachers have personality traits for multicultural education.

Table 2. Teachers' level of having personality traits for multicultural education

\begin{tabular}{llllll}
\hline Sub-dimension & $\begin{array}{l}\text { Number } \\
\text { of Items }\end{array}$ & $\mathrm{N}$ & $\overline{\boldsymbol{X}}$ & $\mathrm{SS}$ & $\begin{array}{l}\text { Average size of the items of dimension } \\
(X \text { / Number of Items })\end{array}$ \\
\hline Cultural Empathy & 11 & 119 & 46,61 & 6,40 & 4.24 \\
Social Initiatives & 6 & 119 & 20,94 & 2,99 & 3.49 \\
Emotional Balance & 7 & 119 & 22,07 & 4,11 & 3.15 \\
Openness & 5 & 119 & 19,33 & 3,38 & 3.87 \\
Flexibility & 4 & 119 & 11,00 & 3,05 & 2.75 \\
Multicultural Personality & 33 & 119 & 118.67 & 12.58 & 3.60 \\
\hline
\end{tabular}

When Table 2 is examined, it is seen that subdimensions of the scale do not contain the same number of items. When interpretation is made for this reason, the item average of the dimensions is calculated. As seen in Table 2, the sub-dimensions of "teachers' multicultural education personality scale" are ranked from highest to lowest in the following order; "Cultural empathy" $(\bar{X} /$ item number $=4.24)$; "Openness" $(\bar{X} /$ item number $=3.87)$; "Social 
enterprise" $(\bar{X} /$ item number $=3.49)$; "Emotional balance" $(\bar{X} /$ item number $=3.15)$ and "elasticity" $(\bar{X} /$ item number $=2.75)$. When the arithmetic mean was interpreted, intervals were evaluated as 1.00-1.79 "fairly low", 1.80-2.59 "low", 2.60- 3.39 "middle", 3.40-4.19 "high" and 4.20-5.00 "very high" (Polat, 2009). In this context, while cultural empathy is "at a fairly high level", openness and social enterprise are at "high level", emotional balance and flexibility is "moderate". When we look at the scale in general, it is understood that teachers are prone to multicultural education "at a high level" ( $X$ / item count $=3.60)$.

\subsection{Findings and Comments From Quantitative Research}

In this chapter, the metaphors produced by the teachers for the concept of multiculturalism and the frequencies of these metaphors are included. Later, the categories created from these metaphoric images were explained by supporting the quotations produced by the teachers. When the metaphorical images that teachers used in relation to the concept of multiculturalism were examined, a total of 116 valid and 65 different metaphorical images were obtained from 119 teachers.

Table 3. Metaphors and Frequencies Related to the Concept of Multiculturalism

\begin{tabular}{llll}
\hline Metaphore images & f & Metaphore images & f \\
\hline Rainbow & 15 & Pilgrimage & 1 \\
Ashura & 6 & Dream & 1 \\
Mosaic & 5 & Tolerance & 1 \\
Rug & 4 & Double-Edged Knife & 1 \\
Greenery & 4 & Light & 1 \\
Spice & 3 & Elixir & 1 \\
Garden & 3 & Istanbul & 1 \\
Crayons & 3 & Kaos & 1 \\
Nature & 3 & Complex Problem & 1 \\
World Kitchen & 3 & Book & 1 \\
Salad & 3 & Community & 1 \\
Cake & 3 & Fruit Plate & 1 \\
Music & 3 & Motifs & 1 \\
Forest & 3 & River Arms & 1 \\
Botanical garden & 3 & Ocean & 1 \\
Treasure & 3 & Piano & 1 \\
Table & 2 & Colors & 1 \\
Wealth & 2 & Picture & 1 \\
Tree & 2 & Clock & 1 \\
Meal & 2 & Art & 1 \\
Sea & 1 & Dinner Table & 1 \\
White Light & 1 & Milk & 1 \\
Bomb & 1 & Council of Poets & 1 \\
Ball-Point Pen & 1 & Team & 1 \\
Paint Pallet & 1 & Field & 1 \\
Sun & 1 & Soil & 1 \\
Bright & 1 & Rain & 1 \\
Lighthouse & 1 & Fan & 1 \\
Ecosystem & 1 & Star & 1 \\
Ecotone & 1 & Puzzle & 116 \\
Universe & 1 & Total & 1 \\
images & & 1 \\
\hline
\end{tabular}

As seen in Table 3 The metaphorical images that teachers produce for the concept of multiculturalism are examined in terms of frequency. The results listed as rainbow (15), ashure (6), mosaic (5), rug (4), greenery (4), spice (3), garden (3), crayons (3), treasure (3), cake (3), music (3), forest (3), salad (3), table (2) and meal (2). Other metaphor images have a only 1 frequency.

\subsection{The Reasons for Teachers' Analogy to the Metaphors Used as a Multicultural Concept}

reasons for analogy of the metaphors that teachers use about the concept of multiculturalism arranged as; the union of differences $(n=81)$, which benefit $(n=22)$, value-added $(n=8)$, the parser $(n=3)$ and unknown $(n=2)$. These categories are cited together with the reasons for the metaphor images obtained in Table 4. 
Table 4. The Reasons for Teachers' Analogy to the Metaphors Used as a Multicultural Concept

\begin{tabular}{|c|c|c|}
\hline Categories & Metaphore İmages & $\mathrm{N}$ \\
\hline $\begin{array}{l}\text { Multiculturalism As A } \\
\text { Coexistence } \\
\text { Differences }\end{array}$ & $\begin{array}{l}\text { Rainbow (15), Ashura (5), Mosaic (5), Rug (4), Greenery (4), Spice (3), Garden (3), Crayons (3), } \\
\text { World Kitchen (3), Music (3), Salad (3), Forest (2), Table (2), Meal (2), Puzzle (1), Ball-Point Pen } \\
\text { (1), Paint Pallet (1), Double-Edged Knife (1), Fruit Plate (1), Council Of Poets (1), Team (1), Dinner } \\
\text { Table (1), Ecotone (1), Community (1), White Light (1), Cake (1), Ecosystem (1), Pilgrimage (1), } \\
\text { Dream (1), Light (1), Motifs (1), Ocean (1), Piano (1), Picture (1), Star (1), Tree (1), Colors (1), } \\
\text { Tolerance (1) }\end{array}$ & 81 \\
\hline $\begin{array}{l}\text { Multiculturalism As A } \\
\text { Beneficiary }\end{array}$ & $\begin{array}{l}\text { Nature (3), Cake (2), Botanical Garden (3), Sea (1), Elixir (1), Book (1), Milk (1), Field (1), Solid } \\
\text { (1), Sun (1), River Arms (1), Clock (1), Art (1), Lighthouse (1), Tree (1), Fan (1), Forest (1) }\end{array}$ & 22 \\
\hline $\begin{array}{l}\text { Multiculturalism As A } \\
\text { Value Adder }\end{array}$ & Treasure (3), Wealth (2), Bright (1), Universe (1), Ashura (1) & 8 \\
\hline $\begin{array}{l}\text { Multiculturalism As A } \\
\text { Separator }\end{array}$ & Rain (1), Bomb (1), Kaos (1) & 3 \\
\hline $\begin{array}{l}\text { Multiculturalism As } \\
\text { An Unknown }\end{array}$ & Complex Problem (1), İstanbul (1) & 2 \\
\hline
\end{tabular}

Some of the participants' opinions regarding the categories shown in Table 4 are as follows:

\section{a) Alignment of Differences}

In this category, 81 metaphors were produced. Teachers perceive multiculturalism as a structure that brings together a wide variety of cultural constructs to enable them to be in harmony. The participants opinions related to this category are as follows:

Multiculturalism resembles the rainbow; because the colors that make up the rainbow are all different, but when they come together they form a magnificent image (Teacher 61)

Multiculturalism is similar to the ashura; because the differences come together and become wealth and abundance (Teacher.29)

Multiculturalism resembles mosaic; because they are strong and beautiful with their differences (Teacher 75).

Multiculturalism resembles rugs; because a harmonious colors and patterns are the whole (Teacher 10)

Multiculturalism resembles a cake; because a homogeneous mixture of many different materials produces an excellent taste (Teacher 9).

\section{b) Providing Benefit}

22 metaphors were produced in this category. Teachers perceive multiculturalism as a means of providing benefits. The participants opinions related to this category are as follows:

Multiculturalism resembles an elixir; because it forms useful mixtures (Teacher 42)

Multiculturalism resembles milk; because we can create different and new tastes (Teacher 2)

Multiculturalism resembles the sun; because it reaches all the different individuals as much as they need (Teacher 86).

\section{c) Adding Value}

8 metaphors were produced in this category. Teachers perceive multiculturalism, which every kind of culture cares about and which is taken into account, as an element that adds value to the environment in which it is practiced. The participants opinions related to this category are as follows:

Multiculturalism resembles colors; because it colors our lives and makes us happy (Teacher 73).

Multiculturalism resembles bright; because you understand not only your own thoughts, but also those of others (Teacher 17).

Multiculturalism looks like the universe; you will understand life better as you discover new cultures (Teacher 19).

\section{d) Dispersive}

Three metaphors were produced in this category. Teachers perceive multiculturalism, where different cultures coexist, as a dispersive situation. Some of the participant's views on this category are as follows:

Multiculturalism resembles a bomb; because the person who wants to shred gives a big trump because multiculturalism is just a very beautiful concept on paper. (Teacher 66).

Multiculturalism resembles rain; because it is different everywhere (Teacher 83). 


\section{e) Unknown}

Two metaphors were produced in this category. Teachers can perceive multiculturalism as an unknown structure. Some of the participant's views on this category are as follows:

Multiculturalism is like chaos; because it is a mixture of many phenomena (Teacher 30).

Multiculturalism resembles Istanbul; because it is the world not fully understood (Teacher 6).

\section{Discussion}

The aim of this research is to examine teachers' personality traits toward multicultural education and their metaphorical perceptions toward the concept of multiculturalism. For this purpose, multicultural personality scale was applied to the teachers. In addition, multicultural metaphors were collected from teachers to determine teachers' metaphorical perceptions toward multiculturalism.

As a result of analyzes made, teachers were found to be highly prone to multicultural education. When teachers' level of having personality traits toward multicultural education is examined, the most prone dimension of teachers is cultural empathy, while the dimension they are most prone to is flexibility. In the study conducted by Eskici (2016), it was found that the most prone dimensions of the teacher candidates in the Multicultural Personality Questionnaire were cultural empathy, while the least likely dimension was flexibility. These results are consistent with the findings of our research. Polat (2009) 's research with teacher candidates found that teacher candidates tend to have multicultural education at the high level and that the most prone dimension of teacher candidates is cultural empathy, while the least likely dimension is the emotional balance. In this respect, it can be said that the findings obtained from the research are similar to those of Polat (2009). Kaya (2013) research has found that teachers find themselves suited to multicultural education. Acar-Çiftçi (2015), on the other hand, found that teachers perceive themselves as competent in terms of cultural competence in their research on their perceptions about their cultural competencies in the context of multicultural education. As a matter of fact, Bennet (2007) shows that the main aim of multicultural education is to increase respect and tolerance and create cultural awareness and to provide the ability to think critically about the prejudices. Washington (2003, etc. Başbay \& Kağnıc1, 2011) describes multicultural teacher competencies as self-understanding, others' understanding of cultures and academic multicultural competences. In light of this information, teachers' tendency towards cultural empathy dimension can be regarded as a positive situation but it is thought that it would be beneficial to carry out the necessary studies while the undergraduate education is in progress, in order to raise the low tendency to the flexibility dimension. Because, individuals with high levels of flexibility can cope with new and unknown situations and can adapt to unexpected situations in other cultures (Polat, 2009).

When the metaphorical perceptions of teachers regarding the concept of multiculturalism are examined, it is seen that most of the teachers perceive multiculturalism as the alignment of differences. Indeed, rainbow, urea and mosaic metaphors that they produce are examples of this. Teachers also perceive multiculturalism as a providing benefit and value-added concept. The attainment of the highest scoring in the cultural empathy sub-dimension of the teachers' Multicultural Personality Questionnaire also supports these views. Multiculturalism was perceived diversity as a harmonious coexistence, that is, as an empathy for cultures. However, very few teachers have chosen to explain multiculturalism as the metaphors that can be defined the dispersive concept and an unknown concept. From this, it can be considered that most of the teachers participating in the research perceive the multiculturalism as a positive concept. Because many studies show that teachers' perceptions towards multiculturalism and multicultural education are positive (Toprak, 2008; Yazıcı, Başol \& Toprak, 2009; Polat, 2012; Kaya, 2013; Bahadır, 2016; Yıldırım, 2016; Okojie-Boulder, 2010; Ware, 2006). Ünlü and Örten (2013) in their research with teacher candidates, point out that it may be beneficial to have training on multiculturalism, since teacher candidates toward multiculturalism may have both positive and negative attitudes.

As a general finding obtained from the research, it is expected condition that a large part of the teachers should have a positive attitude towards multiculturalism, and in this context, they are expected to be prone multicultural education at the high levels and this can be regarded as a positive result. According to Brown and Kysilka (2002), in order to become a multicultural educator, one has to change his mind, his behavior and his belief system by evaluating it. Otherwise, it may cause the teachers to have judgemental and may lead to having prejudices on their students. This research shows that teachers perceive the concept of multiculturalism positively and see themselves as highly susceptible to multicultural education. Thus, this can give clues that the work to be done in the context of multiculturalism can be accepted and successfully implemented by teachers.

\section{Conclusions}

The concept of multiculturalism is shown its effect with increasing speed every day in all geographies. The way in which a successful educational process can be achieved, depends on taking into account the influence of 
multiculturalism. Providing proper education according to multicultural in the education process is through the teachers' multicultural perceptions. Because the teacher is an important building stone of the education process. In this paper these results were found; teachers have high scors of "Multicultural Personality Questionaire". Teachers' multicultural personality has highest scor in $16^{\text {th }}$ item "I pay attention to the face expressions of others" and teachers' multicultural personality has lowest scor in $2^{\text {th }}$ item "I have difficulty communicating with others". The metaphorical images that teachers produce for the concept of multiculturalism are examined in terms of frequency. The results listed as rainbow (15), ashure (6), mosaic (5), rug (4), greenery (4), spice (3), garden (3), crayons (3), treasure (3), cake (3), music (3), forest (3), salad (3), table (2) and meal (2). Also reasons for analogy of the metaphors that teachers use about the concept of multiculturalism arranged as; the union of differences $(n=81)$, which benefit $(n=22)$, value-added $(n=8)$, the parser $(\mathrm{n}=3)$ and unknown $(\mathrm{n}=2)$.

\section{Recommendations}

\subsection{Recommendations for Practitioners}

Activities should organize to prepare students for life in the framework of multicultural education.

While training programs are being organized, necessary arrangements should be made within the framework of multiculturalism

Multicultural education introductory service training activities should be organized for teachers

Multicultural education should be established in the teacher training process

\subsection{Recommendations for Researchers}

Comprehensive research into the importance, benefits and harms of multiculturalism should be undertaken and information should be given to practitioners within the results.

Teachers' perspectives and perceptions towards multicultural education should be examined in different contexts.

Extensive research should be undertaken to explore the underlying causes of teachers' negative perceptions of multicultural education.

\section{Acknowledgement}

This article was presented as abstract at the 3rd International Conference On Lifelong Education And Leadership For All. ICLEL 2017/September 12-14/Polytechnic Instute of Porto, Porto-Portogual.

\section{References}

Acar-Çiftçi, Y. (2015). Teachers'perception of their cultural competencies within the context of multicultural education. (Unpublished doctoral dissertation). Yildiz Technical University, İstanbul, Turkey.

APA (2002). Guidelines on multicultural education, training, research, practice, and organizational change for psychologists. http://www.apa.org/pi/multiculturalguidelines/homepage.html

Bahadır, Ö. (2016). The evaluation of social science teachers' multiculturalism and their multi-cultural education perception. (Unpublished master's thesis). Sakarya University, Sakarya, Turkey.

Baki, A., \& Gökçek, T. (2012). A general overview of mixed method researches. Electronic Journal of Social Sciences, 11(42), 1-21.

Banks, J. A. (1992). Multicultural education: For freedom's sake. EducationalLeadership, 49(4), 32-36. http://www.ascd.org/ASCD/pdf/journals/ed_lead/el_199112_banks.pdf

Banks, J. A. (1993). Multicultural Education: Historical Development, Dimensions, and Practical. Review of Research in Education, 19, 3-49. https://doi.org/10.2307/1167339

Banks, J. A., \& Banks, C. A. (Eds.). (2007). Multicultural education: Issues and perspectives (6th ed.). Hoboken, NJ: Wiley \& Sons

Basbay, A., \& Kagnici, D. Y. (2011). Perceptions of multicultural competence scale: A scale development study. Education and Science, 36(161), 199.

Bennett, C. I. (2007). Comprehensive multicultural education: Theory and Practice (6th edition). Boston: Pearson Allyn and Bacon

Brown, S. C., \& Kysilka, M. (2002). Applying Multicultural and Global Concepts in the Classroom and Beyond. Boston, MA: Allyn ve Bacon.

Cha, Y. K., \& Ham, S. H. (2014). The institutionalization of multicultural education as a global policy agenda. The 
Asia-Pacific Education Researcher, 23(1), 83-91. https://doi.org/10.1007/s40299-013-0088-7

Cirik, I. (2008). Multicultural education and its reflections. Hacettepe University Journal of Education, 34, $27-40$.

Connors-Stack, M. (1995). Multicultural education: A critical analysis of policy and curriculum (Unpublished doctorate dissertation). Memorial University of Newfoundland, Newfoundland, USA.

Creswell, J. (2003). Research design: Qualitative, quantitative and mixed methods approaches (2nd ed.). Thousand Oaks, CA: SAGE Publications.

Creswell, J. W., Plano, C. V. L., Gutmann, M. L., \& Hanson, W. E. (2003). Advanced mixed methods research designs. In A.Tashakkori \& C.Teddlie (Eds.), Handbook of mixed methods in social and behavioral research (pp. 209-240). Thousand Oaks, CA: Sage Publications.

Demir, S. (2012). Importance degree of multicultural education according to Erciyes University faculty members. Turkish Studies, 7(4), 1453-1475. https://doi.org/10.7827/TurkishStudies.3871

Demir, S., \& Basarir, F. (2013). An analysis of pre-service teachers' self-efficacy perceptions in accordance with multicultural education. International Journal of Social Science, 6(1), 609-641.

Duverger, M. (2004). Siyaset sosyolojisi. (Translator: Ş. Tekeli). İstanbul: Varlık Press.

Eskici, M. (2016). Faculty members' opinions about multiculturalism in higher education. Anthropologist, 24(1), 252-261. https://doi.org/10.1080/09720073.2016.11892013

Gay, G. (1994). A synthesis of scholarship in multicultural education. http://files.eric.ed.gov/fulltext/ED378287.pdf

Gay, G. (2014). Kültürel Değerlere Duyarlı Ĕgitim: Teori, Araştırma ve Uygulama. (Translator: H. Aydın) Ankara: Anı Press.

Giannakaki, M. S. (2005). Using mixed-methods to examine teachers' attitudes to educational change: The case of the skills for life strategy for improving adult literacy and numeracy skills in England. Educational Research and Evaluation, 11(4), 323-348. https://doi.org/10.1080/13803610500110687

Giddens, A. (2000). Runaway World : How Globalisation is Reshaping Our Lives. New York: Routledge.

Gollnick, D. M., \& Chinn, P. C. (2009). Multicultural education in a pluralistic society. Upper Saddle River, NJ: Pearson Prentice Hall.

Greene, J. C., Caracelli, V. J., \& Graham, W. F. (1989). Toward a conceptual framework for mixed-method evaluation designs. Educational evaluation and policy analysis, 11(3), 255-274. https://doi.org/10.3102/01623737011003255

Hamilton, R. A. (2015). Multicultural education and high school English teachers: A teacher awareness study (Doctoral dissertation, Florida Atlantic University, Florida, USA).

Kaya, İ. (2007). Minorities, Multiculturalism and Mardin. D.Ü.Ziya Gokalp Education Faculty Journal,9, s. 44-55

Kaya, Y. (2013). Teachers views on multiculturalizm and multicultural education: A Diyarbakır case study. (Unpublished master's thesis). Dicle University, Diyarbakir, Turkey.

Manning, M. L., \& Baruth, L. C. (2009). Multicultural education of children and adolescents. Boston, MA: Pearson.

Miles, M. B., Huberman , M. A. (1994). An Expanded Source Book Qualitative Data Analysis. London: Sage.

Mitchell, B. M., \& Salsbury, R. E. (2000). Multicultural education in the US: A guide to policies and programs in the 50 states. Greenwood Publishing Group.

Nieto, S. (2002). Language, Culture, and Teaching: Critical Perspectives For a New Century. Mahwah, NJ: Lawrence Erlbaum Associates.

Nieto, S., \& Bode, P. (2008). Affirming diversity: The sociopolitical context of multicultural education (5th ed.). New York, NY: Pearson.

Okojie-Boulder, T. (2010). Faculty members' and graduate students' perceptions of multicultural education in the college of education. (Unpublished doctorate dissertation). Mississippi State University, Mississippi, USA.

Özdemir, M., \& Dil, K. (2013). Teachers' attitudes toward multicultural education: Case of Çankırı Province. Ankara University Journal of Faculty of Educational Sciences, 46(2), 215-232.

Özodaşık, M. (2009). Kişilerarası İletişim Sürecinde Algl, İkna ve Empatik İlişkiler (1th. ed.). Konya: Tablet Press.

Parekh, B. (2002). Çokkültürlülüğü Yeniden Düşünmek: Kültürel Çeşitlilik ve Siyasal Teori. (Translator: Bilge Tanrıseven). Ankara: Phoenix Press. 
Polat, S. (2009). Probationary teachers' level of inclination to multi-cultural education. International Online Journal of Educational Sciences, $1(1)$.

Polat, S. (2012). Attitudes of school principals towards multiculturalism. Hacettepe University Journal of Education, 42, 334-343.

Race, R. (2011). Multiculturalism and education: Contemporary issues in education studies. London: Continuum.

Tabatadze, S. (2015). Teachers' approaches to multicultural education in Georgian classrooms. Journal for Multicultural Education, 9(4), 248-262. https://doi.org/10.1108/JME-07-2014-0031

Titrek, O. (2010). The change of School employees' organizational justice (OJ) perceptions concerning geography according to socio-culture. Eurasian Journal of Educational Research, 38, 179-197.

Todor, I. (2015). Integrating Multicultural Education in Pre-Service Teacher Training Courses. The Journal of Linguistic and Intercultural Education, 8, 213.

Toprak, G. (2008). Teacher multıcultural attitude survey. Gaziosmanpaşa University, Tokat, Turkey.

Türkan, A., Aydın, H., \& Üner, S. S. (2016). The Relationship between teacher candidates' attitudes towards multicultural education and their epistemological beliefs. Elementary Education Online, 15(1).

Ünlü, İ., \& Örten, H. (2013). Investigation The Perception of Teacher Candidates About Multiculturism and Multicultural Education. D.Ü.Ziya Gokalp Education Faculty Journal, 21, 287-302.

Valdez, A. (1999). Learning in Living Color: Using Literature to Incorporate Multicultural Education into the Primary Curriculum. Boston: Allyn and Bacon

Ware, F. (2006). Warm demander pedagogy: Culturally responsive teaching that supports a culture of achievement for African American students. Urban Education, 41(4), 427-456. https://doi.org/10.1177/0042085906289710

Yakışır, A. N. (2009). Multiculturalism as a modern fact. (Unpublished master’s thesis). Selçuk University, Konya, Turkey.

Yazici, S., Basol, G., \& Toprak, G. (2009). Teachers' attitudes toward multicultural education: A study of reliability and validity. Hacettepe University Journal of Education, 37, 229-242.

Yıldırım, A., \& Şimşek, H. (2013). Sosyal bilimlerde nitel araştırma yöntemleri (8th ed.) Ankara: Seçkin Press.

Y1ldırım, S. (2016). Examining the relationships of knolwedge, belief, attitude and self - efficiency of teachers toward multicultural education practice in Kosova. (Unpublished doctoral dissertation). Balıkesir University, Balıkesir, Turkey.

\section{Copyrights}

Copyright for this article is retained by the author(s), with first publication rights granted to the journal.

This is an open-access article distributed under the terms and conditions of the Creative Commons Attribution license which permits unrestricted use, distribution, and reproduction in any medium, provided the original work is properly cited. 